\title{
An Integrated Lean Management, IoT and MFCA Systems for Water Management of Industrial Manufacturing in Thailand
}

\author{
Thanwarhat Sodkomkham ${ }^{1, *}$, Chavalit Ratanatamskul ${ }^{2}$, and Achara Chandrachai $^{3}$ \\ ${ }^{1} \mathrm{Ph} . \mathrm{D}$. Candidate, Technopreneurship and Innovation Management Program, Chulalongkorn University, Bangkok, Thailand \\ ${ }^{2}$ Associate Professor, Department of Environment Engineering, Chulalongkorn University, Bangkok, Thailand \\ ${ }^{3}$ Emeritus Professor, Chulalongkorn Business School, Chulalongkorn University, Bangkok, Thailand
}

\begin{abstract}
The study objective was to examine, develop and apply an integrated lean management, IoT and MFCA system to optimize water management of industrial manufacturing in Thailand to increase efficiency. The results of a case study reduced water use in production processes by $15 \%$ per annum, with cost reduction of approximately US $\$ 12,182$. Reduced water consumption renders production processes more environmentally friendly, with increased ease and accuracy in managing water resources. Production processes also become more valuable by applying a modern management approach using industrial engineering techniques that enhance productivity, while reducing costs and increasing competitiveness. Results can be used to balance business development and promote the economy, society and environment in Thailand in the future.
\end{abstract}

\section{Introduction}

Water is an essential resource for the livelihood of humans, animals and plants. Apart from consumption, water is required for animal husbandry and agriculture, and forms the habitat of various fish and aquatic animals. In the industrial sector, water is needed for production processes, cleaning, casting machinery and cooling. Electricity is produced using water as hydroelectric power from dam construction, while water also provides important transportation and tourism routes via rivers, canals, seas and oceans.

The World Resources Institute (WRI) [1] warns that global water resources face an increasing threat through population expansion. By 2025 , over 1 billion people are predicted to live in water-scarce regions, with up to 3.5 billion facing water shortages and increased pollution. Climate change and global warming have altered sedimentation patterns with the deterioration of freshwater and coastal ecosystems. Increased melting of the ice caps will cause future disasters such as flooding and intensified drought. The United Nations has focused on the availability and sustainable management of water and sanitation, highlighted as their Sustainable Development Goals (SDGs) No. 6 [2].

Thailand occupies the 45th position among 164 countries in national water stress rankings [3], with medium-high baseline water stress, and the likelihood of drought risk has been identified in central, northern, western and eastern regions. The Thai Government is aware of the importance of water management and has rolled out a strategy for growth based on an environmentally friendly quality of life, which is included as one of the six strategies expounded in the National Strategy (2018-2037) [4]. The first strategy concerns water management for consumption, which aims to provide clean water supply in all communities and cities. The second strategy involves reassuring the stability of the water supply for production and aims to deliver a reliable water supply for agricultural and industrial sectors. The third strategy addresses flood management, with precautions listed to minimize the impact and damage to communities, economic areas and agricultural areas. The fourth strategy relates to water quality management and preservation of water resources, while the fifth aims to preserve and recover neglected watershed forests. The last strategy pertains to comprehensive adequate and effective management to organize and maintain the watershed. Household water consumption is expected to increase from 2014 to 2027 at an average rate of $1.9 \%$ per annum, while water consumption required by the industrial sector is projected to increase at $4.6 \%$ per annum. The growth of factories and industries has mushroomed in Bangkok and the nearby provinces, especially in the eastern region which is the main industrial area of the country. The Eastern Economic Corridor (EEC) is a strategic plan under the Thailand 4.0 Economic Model that promotes investment in the Eastern Seaboard [5].

This research studied and developed innovative water management, with the aim of reducing production costs by integrating lean management, IoT systems and material flow cost accounting (MFCA) techniques to increase the productivity and efficiency of water management using environmentally-friendly processes.

* Corresponding author: thanwarhat.sd@gmail.com 
Results can be used as management guidelines to standardize the practical management of raw materials and resources, including the efficient use of water.

\section{Literature review}

\subsection{Water management}

Water management can be addressed using the 3Rs concept [6] of reduce, reuse and recycle. These three concepts are expanded upon as follows: 1) Reduce: unnecessary waste as effluent from industrial factories can be reduced to minimize environmental pollution.

2) Reuse: utilize the wastewater by reusing it, thereby bypassing the transformation process and reducing the amount of waste. 3) Recycle: transform the wastewater through various processes and make use of it by other means. Currently, many industrial factories apply the 3Rs concept in developing water recycling and reuse of water to meet specified goals. Wastewater quality can be improved using new water purification technology. In the industrial sector, increased awareness of the importance of water conservation has reduced wastewater discharge. Fillaudeau et al. (2006) studied the brewing industry. Production methods were found to be suitable, using biological alternative treatments such as recycling grain residue for fish food, utilizing organic waste as agricultural fertilizers and installing membrane filter processes to improve wastewater treatment [7]. Environmentally friendly processes have a positive effect on corporate marketing image by reducing the costs of water management and disposal. Continuously searching for new ways to use water in production processes will facilitate better operations. The most cost-effective solution to water problems involves recycling water networks and water reuse [8,9]. Karthik et al. (2011) studied pulp and paper industry factories that consumed a lot of water and generated copious quantities of wastewater. They identified processes to reuse water and waste treatment methods based on the flow characteristics [10], while Hellström et al. (2000) presented a sustainable water management system in Sweden focusing on urban water and wastewater systems. They studied the environmental impact and resource utilization of Swedish urban water systems using a set of sustainability criteria such as health and hygiene, social and cultural aspects, environmental aspects, economic and technical considerations [11]. This concept is suitable and facilitates operations and guidelines for using water in the production process to solve the problems of recycling water networks and recycling water in the most cost-effective way.

\subsection{Lean management}

Lean management relates to a concept of continuous improvement as small incremental changes in production, or organization management to maximize efficiency. Waste reduction is considered at every step of the process, whether this involves the production line, logistics, or meeting the demands of the markets and customers [12].
Lean management prioritizes maximum productivity while minimizing waste during continuous production flow processes. Lean manufacturing tools include value stream analysis that starts with a production diagram using value stream mapping (VSM). The value stream covers the whole assignment of aspects that increase the value and decrease the value to create the products [13]. The lean concept has proved beneficial for the operation of efficient economy in many cases.

Dieste et al. (2018) researched the Lean Six Sigma principles in a water management system using a combination of water efficiency and leakage detectors in the distribution system [14, 15], while Tayyab et al. (2020) investigated the simulation of production systems considering wastewater and environmental policies in the textile industry. They used the concept of lean philosophy to enhance investment analysis and decision-making on the cost of wastewater treatment. Their results indicated a reduction in the amount of effluent by $12.56 \%$ and cost of variable $\mathrm{CO}_{2}$ emissions by $20.98 \%$ that positively impacted environmental impact and stimulated economic growth [16]. Efforts have also been made to reduce the amount of wastewater and evaluate water usage alternatives [17] to lay out appropriate guidelines and strategies for saving water in large industrial estates.

\subsection{Internet of things: loT}

Kevin Ashton first coined the term the Internet of Things (IoT) in 1999. While working on a research project at Massachusetts Institute of Technology (MIT) [18], Ashton suggested that any electronic device that could transmit or communicate was considered "Internet-like", meaning that an electronic device communicates in the same way as the internet. The word "things" refers to those electronic devices. Nowadays, information on smart sewage is used to enable the "Internet of Things" and manage wastewater in real time. This allows early prediction of a possible impact in case of a flood, which is vital for future operational management of a sewage network. Wang et al. (2013) demonstrated real-time operations in China to monitor and report on the efficiency of the sewage system [19]. The Environmental Internet of Things (EIoT) concerns the management of water quality in main city rivers. One of the EIoT components is an Online Water Quality Management System (OWQMS), which consists of 1 ) an online system that monitors the water quality, 2) a digital data transfer system, and 3) a data processing system. Cherukutota and Jadhav (2016) proposed a development guideline architectural framework of a smart water meter using IoT environmental monitoring [20]. This is an open source platform for rapid prototyping of IoT devices where data can be stored and analysed on the cloud. Users can also access, analyse and share information anywhere and anytime [21]. In a similar vein, Edmondson et al. (2018) adopted the Internet of Things for operational wastewater management to control and report intelligent effluent data using building information modelling (BIM) with distributed smart sensors [22]. Result showed that this system could monitor and report on the performance of 
urban drainage systems in real time to predict upcoming floods and their impacts. These online systems will guide the development of smart cities and environmental sustainability in the future $[23,24]$.

\subsection{Material flow cost accounting: MFCA}

Material flow cost accounting: MFCA or ISO 14051:2011 (E) [25] is an environmental management tool. MFCA was created to increase material and energy usage, while reducing cost and waste/emission and/or non-products generated during a production process that are physical materials with monetary values. MFCA displays transfer and change in values of raw materials after processing, while also identifying or indicating opportunities for improvement in raw material usage with increased efficiency. The cost of material losses in products with negative value can be divided into four types as 1) Material cost, 2) Energy cost, 3) Processing or system cost, and 4) Waste emission cost. Case studies on the effectiveness of MFCA have identified the cost of production not related to products. This reflects the process efficiency and encourages optimization of company resources [26], while simultaneously considering economic, environmental, and social responsibilities [27]. Fakoya et al. (2013) studied the integration of MFCA and enterprise resource planning (ERP) systems [28] to identify hidden costs embedded in the manufacturing process, and how MFCA helps to prioritize waste recovery through material or mass balances and cost computation analysis to support decision-making in waste management [29, 30]. A literature review by Christ et al. (2015) suggested that the potential benefits of using MFCA in the business world included improving efficiency and reducing material costs, enhancing resource management systems to find new solutions, and using innovations in the production processes [30].

\section{Methodology}

\subsection{Development of an integrated lean management, IOT and MFCA systems for water management}

This study focused on production processes and observed current problems in industrial factories that use massive amounts of water in the production process to create an innovative water management development process and reduce industrial production cost by applying lean management, IoT and MFCA systems in six steps as follows:

- Step 1: Use value stream mapping (VSM) to analyse the process and reduce waste

Three categories were identified as a) Value added (VA) as a transformation that adds values to raw materials, products from the process, and the complete products, b) Necessary but non-value added (NNVA) as a necessary non-value waste in the production process, and c) Non-value added (NVA) as a waste that needs to be removed by value stream mapping. Lean value stream maps add information on water use to identify wastewater, and develop implementation plans for lean and water efficiency improvement efforts. These include reuse or recycling of waste management in the production process. - Step 2: Observe and apply the Gemba walk

The Gemba walk is an opportunity for staff to take a step back from their daily tasks and walk the floor of their workplace to identify wasteful activities. A team walk the factory floor together to observe and record inefficiencies related to water use. Water balance and VSM are conducted to examine water usage in each step of the process. A diagram of the facility's water usage is developed that shows, quantifies and adopts the $3 \mathrm{R}$ concept (reduce, reuse, recycle) in each step of the process for water management.

- Step 3: Use material flow cost accounting (MFCA)

MFCA is utilized to study and analyse the cost that occurs in the whole process: Input $=$ Output (Product + Waste) such as water fee, the cost of water treatment within the factory, and the cost of water treatment in the industrial estate.

- Step 4: Staff and personnel related to the process hold a meeting and brainstorm using root cause analysis methods to explore the underlying causes of wastewater and inform improvements.

- Step 5: Staff and personnel related to the process kickoff the plan or measures using PDCA principles that consist of a) Plan, b) Do, c) Check, and d) Act to make the appropriate adjustments.

- Step 6: An integrated lean management, IoT and MFCA system is proposed for water management of industrial manufacturing (Figure 1) that could be used in a factory to improve efficiency.

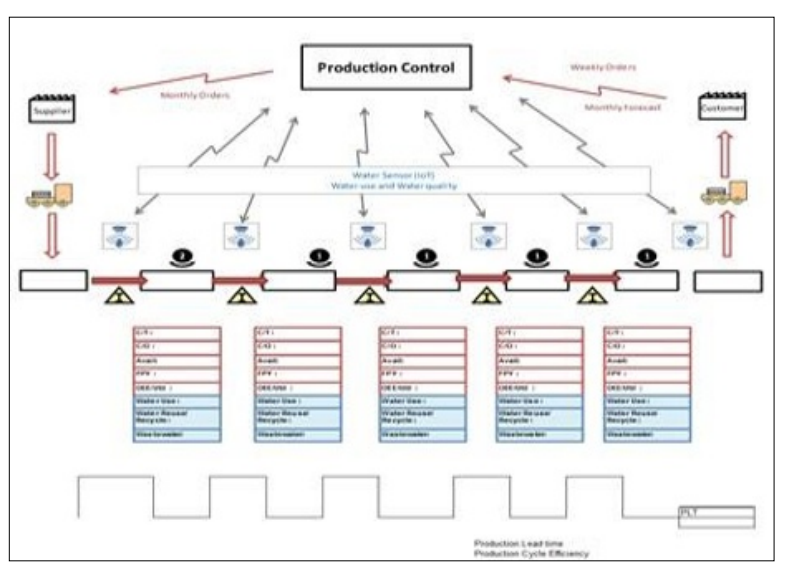

Fig. 1. Develop innovative water management and cost reduction from industrial manufacturing process by application of lean management, IoT and MFCA systems.

\subsection{Data collection}

The case study was an electronics factory that mainly produced compressors. The manufacturing process of a rotary compressor for air-conditioning began by preparing the material and parts for assembly into the finished product. The production process flow can be summarized into nine major steps as follows:

- Process 1: Rough-machining process (turning/drilling) 
The process of roughing (turning/drilling) of machine parts includes casting, sintering, and forging.

- Process 2: Finish-machine process (grinding)

In this process, machining parts from process 1 are ground to ready them for the next assembly process. Parts are cleaned using a cleaning machine before assembly.

- Process 3: Sub assembly process

Finished machining parts from process 2 are assembled in this process.

- Process 4: Motor winding process (winding)

Laminated metal copper wire is used as a raw material in the motor winding process. The finished product is used as one of the main inputs for assembly in process 8 .

- Process 5: Piping process welding (welding)

Pressed metal is welded in the piping process.

- Process 6: Casing assembly process (welding blaze)

Output from process 5 is subjected to the casing assembly process. Finished welded articles are used as one of the main inputs for assembly in process 8 .

- Process 7: Accumulator assembly process

Output from the accumulator assembly is used as one of the main inputs for assembly in process 8 .

- Process 8: Assembly process

Parts from process 3 , the motor from process 4 , casing from process 6 , and the accumulator from process 7 are assembled in process 8 by shrink fit welding to make the rotary compressor for the air conditioner, before testing as the last process prior to customer delivery.

- Process 9: Painting and finish process

Compressors from process 8 will be painted and filled with oil in this process to make finished products (figure 2).

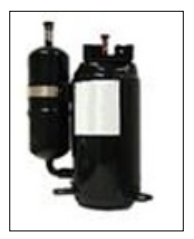

Fig. 2. Finished product (Compressor for air conditioner)

Table 1 shows the data collection structure that could be used to develop innovative water management and cost reduction in an industrial manufacturing process by integrating lean management, IoT and MFCA systems to maximize water use efficiency in industrial factories.

Table 1. Data collection structure.

\begin{tabular}{|c|c|c|c|}
\hline Tools & Input & Process & Output \\
\hline $\begin{array}{c}\text { Lean } \\
\text { management }\end{array}$ & $\begin{array}{l}\text { - Material } \\
\text { - Water }\end{array}$ & $\begin{array}{l}\text { - WIP (Work } \\
\text { in process) } \\
\text { - Waste/Loss } \\
\text { - Wastewater }\end{array}$ & $\begin{array}{l}\text { - Product } \\
\text { - Waste/Loss } \\
\text { - Wastewater }\end{array}$ \\
\hline $\begin{array}{c}\text { Internet of } \\
\text { things (IoT) } \\
\text { : Water } \\
\text { sensor }\end{array}$ & $\begin{array}{l}\text { - Detect } \\
\text { amount of } \\
\text { water } \\
\text { inputs } \\
\text { - Detect } \\
\text { quality of } \\
\text { water } \\
\text { inputs }\end{array}$ & $\begin{array}{l}\text { - Detect water } \\
\text { usage in each } \\
\text { process } \\
\text { - Detect } \\
\text { amount of } \\
\text { wastewater in } \\
\text { each process }\end{array}$ & $\begin{array}{l}\text { - Detect } \\
\text { amount of } \\
\text { wastewater } \\
\text { outputs } \\
\text { - Detect } \\
\text { quality of } \\
\text { water outputs }\end{array}$ \\
\hline
\end{tabular}

\begin{tabular}{|c|l|l|l|}
\hline & - Cost of & - Cost of & - Cost of \\
Material & water & water & water \\
flow cost & from & treatment & treatment in \\
$\begin{array}{c}\text { accounting } \\
\text { (MFCA) }\end{array}$ & source & before being & the industrial \\
& & $\begin{array}{l}\text { released to the } \\
\text { industrial } \\
\text { estate }\end{array}$ & estate \\
& & \\
\hline
\end{tabular}

\section{Results}

The case study was used to determine an industrial manufacturing process by application of lean management, IoT and MFCA systems for the production process. First, to find the cause of problems and waste in the process, lean management was applied to analyse the inputs, processes and outputs. Team brainstorming suggested ways to reduce water use by recycling wastewater in the processes following the 3Rs (reduce, reuse, recycle). The case study was performed on a factory that adopted innovative water management and cost reduction for industrial manufacturing production processes by applying lean management, IoT and MFCA systems. Table 2 shows the operating results from January to December 2019, including replacing and installing automatic water-saving faucets to reduce water use by $2,400 \mathrm{~m}^{3}$. Water use was reduced by $6,540 \mathrm{~m}^{3}$ by using recycled water from rainfall rooftop collection in water storage tanks, and RO water was reused in the deionized water system in the machine, boiler and cooling tower at $15,000 \mathrm{~m}^{3}$. Thus, total amount of water reused and recycled was $23,940 \mathrm{~m}^{3}$. Total water use in the factory was $155,974 \mathrm{~m}^{3}$. Actual water consumption at $0.0030 \mathrm{~m}^{3} /$ product/year was reduced by up to $15 \%$ per annum.

Table 2. Results of implementation planning in the electronic industrial factory case study.

\begin{tabular}{|c|c|c|c|}
\hline \multirow{2}{*}{ Data collection } & \multicolumn{3}{|c|}{ Results } \\
\hline & $\begin{array}{l}\text { Year } \\
2017\end{array}$ & $\begin{array}{l}\text { Year } \\
2018\end{array}$ & $\begin{array}{l}\text { Year } \\
2019\end{array}$ \\
\hline Total pieces per year & $4,187,604$ & $4,849,586$ & $5,175,244$ \\
\hline $\begin{array}{l}\text { Total water use in } \\
\text { factory }\left(\mathrm{m}^{3}\right)\end{array}$ & 153,151 & 162,847 & 155,974 \\
\hline $\begin{array}{l}\text { Amount of surface } \\
\text { water or tap water } \\
\text { used }\left(\mathbf{m}^{3}\right)\end{array}$ & 142,003 & 150,492 & 132,034 \\
\hline $\begin{array}{l}\text { - Amount of water used } \\
\text { in the manufacturing } \\
\text { process }\left(\mathrm{m}^{3}\right)\end{array}$ & 115,670 & 125,098 & 110,040 \\
\hline $\begin{array}{l}\text { - Amount of water used } \\
\text { in the office buildings } \\
\text { and others }\left(\mathrm{m}^{3}\right)\end{array}$ & 26,333 & 25,394 & 21,994 \\
\hline $\begin{array}{l}\text { Amount of water } \\
\text { treatment }\left(\mathbf{m}^{3}\right)\end{array}$ & 77,544 & 78,130 & 77,895 \\
\hline $\begin{array}{l}\text { - Amount of water } \\
\text { reuse and recycling } \\
\left(\mathrm{m}^{3}\right)\end{array}$ & 11,148 & 12,355 & 23,940 \\
\hline $\begin{array}{l}\text { - Amount of } \\
\text { wastewater } \\
\text { (water discharge) }\left(\mathrm{m}^{3}\right)\end{array}$ & 66,396 & 65,775 & 53,955 \\
\hline
\end{tabular}




\begin{tabular}{|l|c|c|c|}
\hline $\begin{array}{l}\text { Percentage of water } \\
\text { sources (\%) }\end{array}$ & $\begin{array}{c}\text { Year } \\
\mathbf{2 0 1 7}\end{array}$ & $\begin{array}{c}\text { Year } \\
\mathbf{2 0 1 8}\end{array}$ & $\begin{array}{c}\text { Year } \\
\mathbf{2 0 1 9}\end{array}$ \\
\hline $\begin{array}{l}\text { - Surface water or tap } \\
\text { water }\end{array}$ & $93 \%$ & $92 \%$ & $85 \%$ \\
\hline - Ground water & - & - & - \\
\hline $\begin{array}{l}\text { - Water reuse and } \\
\text { recycling }\end{array}$ & $7 \%$ & $8 \%$ & $15 \%$ \\
\hline $\begin{array}{l}\text { Actual of water used } \\
\text { (m)/product) }\end{array}$ & 0.037 & 0.034 & 0.030 \\
\hline
\end{tabular}

In terms of the IoT, water sensors were installed and set to send and receive data every hour. The objective of this action was to proactively control water use by monitoring and detecting anomalies and water quality in tap water and recycled water. Results can be used for predictive maintenance to reduce the probability of failure and downtime and, thereby, increase productivity.

In the same way, water management costs were recorded and assessed by material flow cost accounting (MFCA). Comparison of the results showed that 150,492 $\mathrm{m}^{3}$ of surface water or tap water was used in 2018, while implementation of industrial manufacturing processes by applying lean management, IoT and MFCA systems reduced this by $18,458 \mathrm{~m}^{3}$ to $132,034 \mathrm{~m}^{3}$ in 2019 . The Amata Industrial Estate water tariff rate is US\$0.66 per cubic meter; thus, production costs were reduced by approximately US\$12,182 per annum.

\section{Discussion}

Global warming and climate change have resulted in extremes of weather. Droughts, floods, melting glaciers impacting sea level rise and storms have intensified. Climate change directly affects water security. Thailand is currently experiencing water shortages from the increasing demand of water for consumption and use in agriculture. Water usage in the industrial sector on industrial estates and in Eastern Economic Corridor (EEC) areas is increasing. The industrial sector is considered important for the future growth of the Thai economy.

Results of the case study that adopted innovative water management for industrial manufacturing processes by applying lean management, IoT and MFCA systems showed reduction of water usage at $15 \%$ per annum or a cost reduction of US $\$ 12,182$. Future research should include additional factors involved in integrating lean management, IoT and MFCA systems for water management of industrial manufacturing, including types of industry, processes and skills of employees. External factors also influence the development of laws and regulations, disasters and natural phenomena that impact the economy and global trends.

\section{Conclusion}

Development of an innovative water management system for industrial manufacturing processes by applying lean management, IoT and MFCA could be used to optimize water usage accuracy in real time. The case study showed reduced production costs and an increase in water use efficiency that could be used as guidelines to develop sustainable future water management in the Thai industrial sector.

\section{References}

1. World Resources Institute (WRI). Mapping, measuring, and mitigating global water challenges, Available from: <https://www.wri.org/ourwork/topics/water> (accessed 09.09.2020)

2. United Nations, The Sustainable Development Goals -SDGs) Goal 6: Ensure access to water and sanitation for all, Available from: <https://www.un. org/sustainabledevelopment/water-and-sanitation/> (accessed 09.09.2020)

3. H. Rutger Willem, R. Paul, and S. Leah. 17 Countries, Home to One-Quarter of the World's Population, Face Extremely High Water Stress, Available from: <https://www.wri.org/blog/ 2019/08/17-countries-home-one-quarter-worldpopulation-face-extremely-high-water-stress> (accessed 09.09.2020)

4. National Strategy and Country Reform, Thailand's 20-Year National Strategy 2018 - 2037, Available from: <http://nscr.nesdb.go.th/wp-content/uploads /2019/10/National-Strategy-Eng-Final-25-OCT2019.pdf> (accessed 18.09.2020)

5. Eastern Economic Corridor (EEC), The Eastern Economic Corridor (EEC) Development Plan under scheme of Thailand 4.0, Available from: <https://www.eeco.or.th/en/government-initiative> (accessed 18.09.2020)

6. H. Takiguchi and K. Takemoto, Japanese $3 R$ Policies Based on Material Flow Analysis, J. Ind. Ecol., 12, 792-798 (2008)

7. L. Fillaudeau, P. Blanpain-Avet, and G. Daufin, Water, wastewater and waste management in brewing industries, J. Clean. Prod., 14, 463-471 (2006)

8. R. F. Dunn and H. Wenzel, A process integration design method for water conservation and wastewater reduction in industry, Comput. Aided Chem. Eng., 9, 985-990 (2001)

9. F. A. El-Gohary, S. I. Abo-Elela, and H. I. Ali, Management of wastewater from soap and food industries: A case study, Sci. Total Environ., 66, 203-212 (1987)

10. M. Karthik, R. Dhodapkar, P. Manekar, P. Aswale, and T. Nandy, Closing water loop in a paper mill section for water conservation and reuse, Desalination, 281, 172-178 (2011)

11. D. Hellström, U. Jeppsson, and E. Kärrman, A framework for systems analysis of sustainable urban water management, Environ. Impact Assess. Rev., 20, 311-321 (2000) 
12. N. V. K. Jasti, and R. Kodali, Lean production: literature review and trends, Int. J. Prod. Res., 53, 867-885 (2014)

13. M. Dieste, R. Panizzolo, J. A. Garza-Reyes, and A. Anosike, The relationship between lean and environmental performance: Practices and measures, J. Clean. Prod., 224, 120-131 (2019)

14. R. Cairns and M. Macpherson, A Six Sigma Approach to Water Savings, Environmental Management and Sustainable Development, 6, 98-111 (2017)

15. S. Ngoune and P. Kholopane, The application of Lean Six Sigma in alleviating water shortage in limpopo rural area to avoid societal disaster, PICMET 2016, 2386-2391 (2016)

16. M. Tayyab, J. Jemai, H. Lim, and B. Sarkar, A sustainable development framework for a cleaner multi-item multi-stage textile production system with a process improvement initiative, J. Clean. Prod., 246, 119055 1-20 (2020)

17. N. Norani, H. Ashari, and M. Rajemi, A Case Study of Sustainable Manufacturing Practices, J. Adv. Manag. Sci., 2, 12-16 (2014)

18. A. Kevin, That 'internet of things' thing, RFID journal, 22, 97-114 (2009)

19. S. Wang, Z. Zhang, Z. Ye, X. Wang, X. Lin, and S. Chen, Application of Environmental Internet of Things on water quality management of urban scenic river, Int. J. Sustain. Dev. World Ecol., 20, 216-222 (2013)

20. N. Cherukutota and S. Jadhav, Architectural framework of smart water meter reading system in IoT environment, ICCSP 2016, 0791-0794 (2016)

21. D. Koo, K. Piratla, and C. J. Matthews, Towards Sustainable Water Supply: Schematic Development of Big Data Collection Using Internet of Things (IoT), Procedia Eng., 118, 489-497 (2015)

22. V. Edmondson, M. Cerny, M. Lim, B. Gledson, S. Lockley, and J. Woodward, A smart sewer asset information model to enable an 'Internet of Things' for operational wastewater management, Autom. Constr., 91, 193-205 (2018)

23. S. Bibri, The IoT for Smart Sustainable Cities of the Future: An Analytical Framework for Sensor-Based Big Data Applications for Environmental Sustainability, Sustain. Cities Soc., 38, 230-253 (2017)

24. X. Mo, J. Qiu Xin, and S. Shen, An IoT-Based System for Water Resources Monitoring and Management, IHMSC 2015, 2, 365-368 (2015)

25. International Organization for Standardization (ISO), ISO 14051:2011(en) Environmental management Material flow cost accounting - General framework, Available from: <https://www.iso.org/obp/ui/\#iso: std:iso:14051:ed-1:v1:en.> (accessed 28.09.2020)

26. M. Yagi, and K. Kokubu, Corporate material flow management in Thailand: The way to material flow cost accounting, J. Clean. Prod., 198, 763-775 (2018)
27. Y. K. Wan, R. T. L. Ng, D. K. S. Ng, and R. R. Tan, Material flow cost accounting (MFCA)-based approach for prioritisation of waste recovery, J. Clean. Prod., 107, 602-614 (2015)

28. M. B. Fakoya and H. M. van der Poll, Integrating ERP and MFCA systems for improved wastereduction decisions in a brewery in South Africa, J. Clean. Prod., 40, 136-140 (2013)

29. T. V. Bartholomew and M. S. Mauter, Multiobjective Optimization Model for Minimizing Cost and Environmental Impact in Shale Gas Water and Wastewater Management, ACS Sustain. Chem. Eng., 4, 3728-3735 (2016)

30. K. L. Christ and R. L. Burritt, Material flow cost accounting: a review and agenda for future research, J. Clean. Prod., 108, 1378-1389 (2015) 